International Journal of Scholarly Papers for Media and Communications

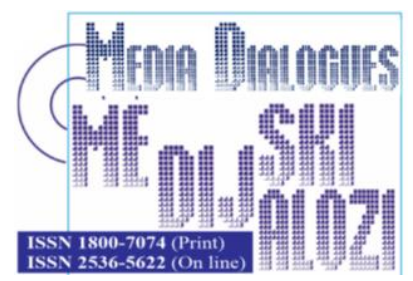

Corovic, B., Janicic, R. (2020), „Holistic Marketing Approach of Educational Process in Modern Media Environment", Media Dialogues / Medijski dijalozi, Vol. 14, No. 2, pp. 31-40.

\title{
Holistic Marketing Approach of Educational Process in Modern Media Environment
}

\author{
BEKIM COROVIC, \\ University of Belgrade, Faculty of Organizational Sciences, \\ Belgrade, Serbia \\ RADMILA JANICIC, \\ University of Belgrade, Faculty of Organizational Sciences, \\ Belgrade, Serbia
}

\begin{tabular}{|c|c|}
\hline $\boldsymbol{A} \boldsymbol{R} \boldsymbol{T} \boldsymbol{I} \boldsymbol{C L} \boldsymbol{E}$ & Received: November 07, 2021 / Revised from: December 07, 2021 \\
$\boldsymbol{I} \boldsymbol{N} \boldsymbol{F} \boldsymbol{O}$ & Accepted: January 08, 2021 / Available online: October 15, 2020 \\
\hline DOI & doi.org/10.14254/1800-7074/13-4/3 \\
\hline
\end{tabular}

\begin{abstract}
The paper gives theoretical and practical approach to challenging educational process in modern environment. In first part of paper, present theoretical aspects of educational process through history and time, by leading authors in the field of education. Educational process comes from traditional form of teaching to integrated learning process, which includes information technology platforms, modern holistic marketing approach, modern approach to presentation in class room, interactive
\end{abstract}


discussion with students, and use of mobile platforms and new concept of relationship with students, based on dialogue. Also, business environment has changed and has impacted educational process. In second part of paper, is presented theoretical aspects of student's behavior through time, from traditional concept of listening lectures, to the interactive learning process and dialogue with colleagues and professors. Also, changing business environment bring to educational process new topics, new professions. There is emphasizing that new generation need integrated approach, based on both traditional knowledge methodologies and information technologies platforms. Young generations love to share knowledge, educational experiences and have strong feeling for connection with others, to learn more, to travel, to get experiences. Young generations are mobile and in looking for knowledge and nontraditional professions. Professors have to follow these educational and business changes. In third part of paper, is presented empirical research about student's behavior in modern educational process and new business environment. Empirical research includes questionnaire and focus group by students about their new needs, wishes and feelings in modern educational process in modern environment. Empirical research presents what drives students in education, in getting knowledge.

KEYWORDS: Student's Behavior, Educational Process, Information Technology Platforms, Integrated Educational Approach, Share of Knowledge

\section{INTRODUCTION}

The paper will give theoretical and practical approach to challenging educational process in modern media environment. Educational process comes from traditional form of teaching to integrated learning process, which includes information technology platforms, modern approach to presentation in class room, interactive discussion with students, use of mobile platforms and new concept of relationship with students, based on dialogue. Also, business environment has changed and has impacted educational process. Changing business environment bring to educational process new topics, new professions. There is emphasizing that new generation need integrated, modern approach, based on both traditional knowledge methodologies and information technologies platforms. New student's generations need traditional lectures, dialogue with professor, but also, wide range of information technologies platforms where they can find presentations, forums, all information's. New student's generations look for education in alternative forms on Internet, like YouTube educational channels, TED, Universities channels, young conferences.

Young generations love to share knowledge, educational experiences and have strong feeling for connection with others, to learn more, to travel, to get experiences. Young generations are mobile, fast and in looking for knowledge and nontraditional professions. They use social media for education. They love to share knowledge and 
experiences. Professors have to follow these educational and business changes. Student's behavior changed in modern educational process and new business environment. Today, students need information technology platforms for education. Students are inspire to learn, they are looking for new knowledge, either in traditional and modern ways.

Nelson Mandela said, "Education all of our children must be one of our most urgent priorities. We all know that education, more than anything else, improves our chances of building better lives." Aristotle said, "Educating the mind without educating the heart is no education at all", what give us point that as professors we have to follow our students in their needs, wishes and new approach to education. Education is way for the future, so with learning young generations we create future world. Professors have responsibility to realize student's behavior, to help them to learn in their own ways.

\section{CHALLENGE IN EDUCATIONAL PROCESS IN MODERN ENVIRONMENT}

Challenge in education process in modern media environment has to be innovative and creative. Holistic marketing approach is one of the ways for modernization of educational process. Holistic marketing approach has challenge in improving planning process of education in modern environment. All parts of holistic marketing approaches are important, internal marketing, integrated marketing (Belch, G. \& Belch, M., 2012; Kennet, 2008), relationship marketing and social responsible marketing. Internal marketing strategies improve organizational structures of educational process and communications with students and professors. Strategies of integrated marketing improve consistent of educational process in modern environment. Social responsible approach is base of every education. The key message of education is learning, sharing, succeed and social changes. Strategies of relationship marketing make platforms for clear and direct communications with target audiences of educational process. In all these ways holistic marketing approach is base platform for realization of educational process. The elements of holistic marketing approach are present on Figure 1.

Implementation of holistic marketing approach in educational process is challenging, because target audiences are sophisticated, process of planning and organizing of education is requesting, as well as, social responsibility is strong. Strategies of relationship marketing and modern media give opportunities for direct communication with target audiences. It is important to make good connections with audiences of educational process, as well as, trust, based on truth and openness of professor's stuff. The key strategies in educational process are strategies of innovations, strategies of adaptation, strategies of relationship marketing, social responsible strategies and strategies of communications with target audiences. 


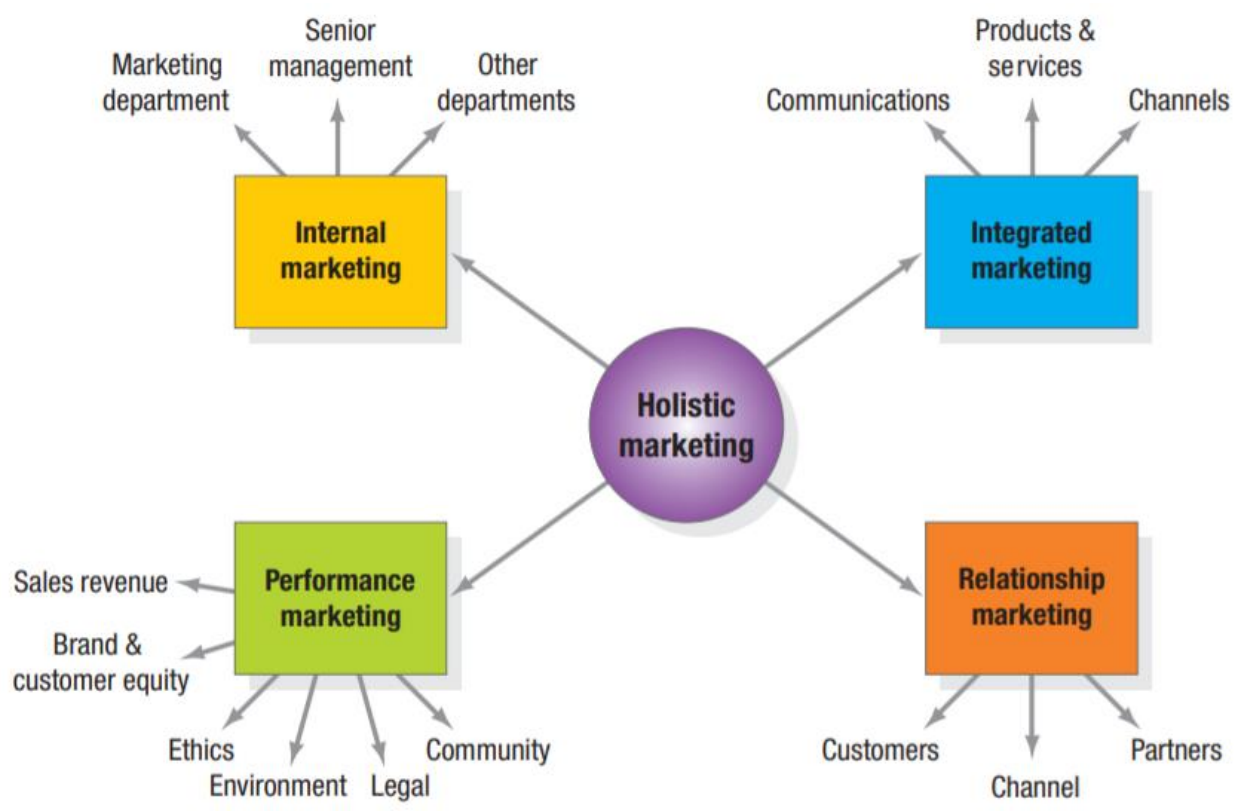

Figure 1. Elements of holistic marketing approach

Source: Kotler \& Keller, 2016, p. 19.

Many educational process include students, using volunteer work, focus group discussion, and social media discussion and in the way of interactive communications with students and professors. Educational process has social responsible impact on better business development, on raising awareness about social problems, through history. Education has impact on social movements, as well as, improves social awareness about social problems. History facts prove that education develop awareness about future movements. Educations are the base for development of modern society. Modern society needs interactive communications through modern media about educational process. Educational institutions send messages to audiences and, also, listen needs and wants of target audiences. Specific opportunities of social media are that educational institutions can impact on awareness and attitude of public audiences.

Holistic marketing approach has integrated marketing communication with target audiences, which present opportunities for research needs and wants of students, as well as, social movements. It is very important that integrated marketing communications (Blakeman, 2006; David, 2005; Larry, 2008; Terence, 2008) of educational institutions have consistent storytelling with target audiences. Education send social impulses to public and call people to think about social problems, ways, social attitude, young people, future, modern civilizations, life, life stories, history, sociology. In that way education drive people to react, to have atittude, to communicate with 
other people and to create better world. Educational projects are creative and drive public to think and feel (Pelsmacker, 2007). The creative educational idea motivate public, as well as, creative idea is original approach, base on imagination. Creative idea has to be clear, simple and inspire (Reid et al., 2008). Strategies of public relations are very important in educational prcess. These strategies improve communications and connections between educa-tional institutions and target audiences (Pelsmacker, 2007; Pelsmacker et al., 2007).

Strategies of public relations develop and improve communications between educational institutions and their target audiences. Social responsible approach gives platform for educational projects, as well as, purpose and message to target audiences. Strategies of relationship marketing have specific impact in leading of educational projects. They give opportunities of interactive communications with students, public, through traditional ways of communication and modern, social media. Two way communications give opportunities for listening of wants and needs of students, public, that shows ways for furture development (Kotler, 2008). Media communications are part of educational projects. Media culture is also culture of high technology. This need technology gives opportunities for better communications and gives to educational projects global dimension (Kelner, 2004). "Education all of our children must be one of our most urgent priorities. We all know that education, more than anything else, improves our chances of building better lives" (N. Mandela).

\section{SOCIAL MEDIA AND EDUCATION}

Social media gives great opportunities in educational process in modern environment. Students can be informed and inspired to learn about history, sociology, archeology, arts, to follow their interests, through many social media channels. Students can follow travel's vlogs on Instagram and be inspired to learn more about geography. They can follow TEDex YouTube channel and learn about every their interesting topics, or they can share their experiences, by YouTube, about learning, educational process and future desires for education. Young generations today want to share stories, experiences. Their philosophy is that it is important to share education, experiences, life stories, in order to inspire each others. Student's conferences always have share word in the name of conference. Education today is base on innovation, motivation, digital media, communications and share of learning process.

In this new digital environment, it is important that professors accept technology, as modern approach to education. Also, it is important that professors improve their pedagogical skills, in the way to open mind and heart, and understand young generations. There are so many ways to teach students, to inspire them and to motivate them. Modern environment requires modern pedagogic and professors. Many schools and faculties have information platform for educational process. In that way, students can read materials after school, but also can ask professors about educational topics. Experience of professors in focus group tell us that students want to 
have materials online, but also, want communications with professors. The landscape of social media is present in Figure 2.

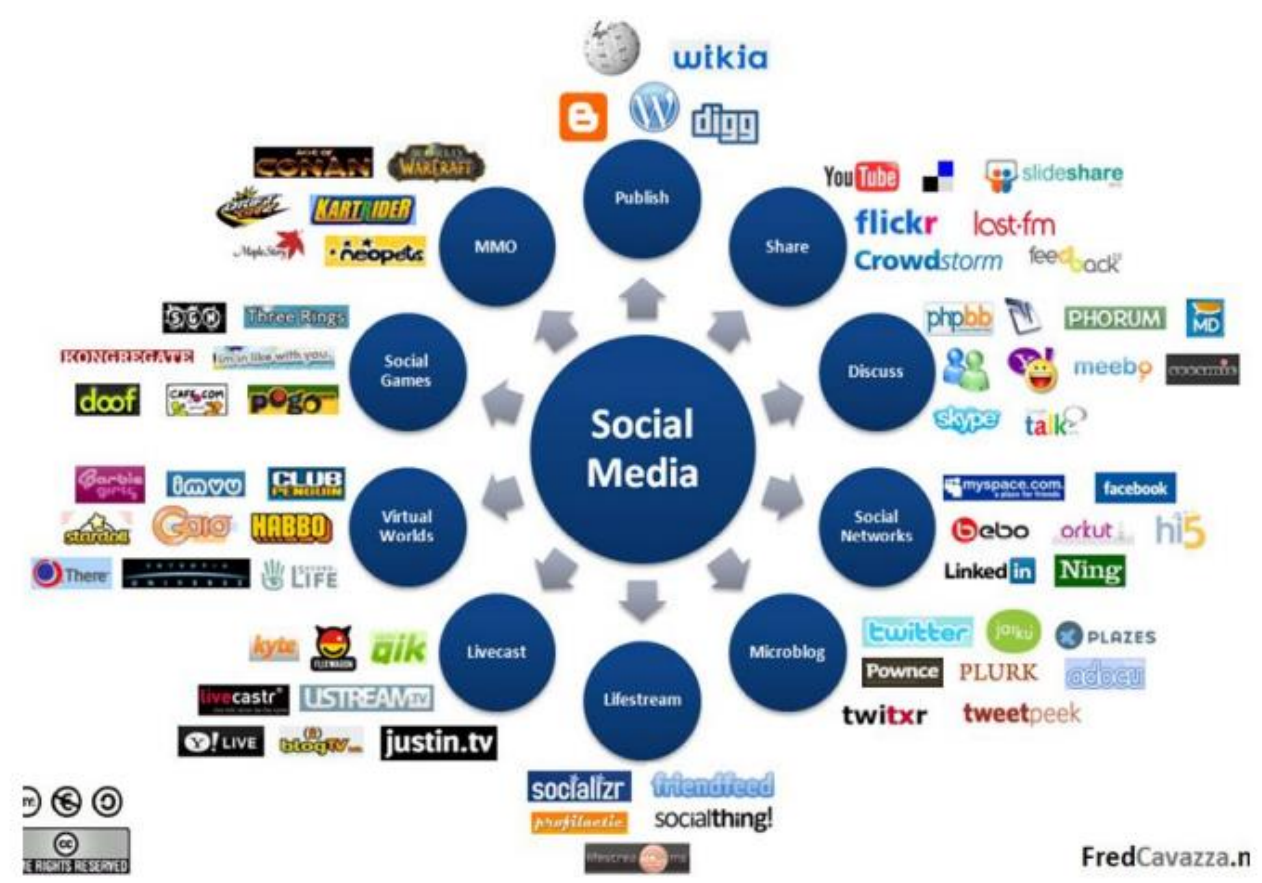

Figure 2. Landscape of social media

Source: Janicic, 2018.

From history it is known that education solving problems. Professors have to follow new technological trends, but also professors have to be with objective attitude with students in new environment. Professor have to implement responsible education in new business and social environment. Socrates said that secret of change is to focus all your energy not on fighting the old but on building the new. N. Mandela said that education is the most powerful weapon which you can use to change the world.

Focus groups have organized by six professors from Faculty of Organizational Sciences. The conclusions of focus group are that students need all information's online, that students can equal learn online and in traditional ways in classroom, that students want communications with professors in classroom and at consultations, that students need inspirations, motivations, that students have new inspiring person, like managers in public and private corporations, travelers, bloggers, vloggers, writers, that young generations are prepare for responsible work and that they are brave 
to start new business, that they are brave to organize start-up and to improve business. The conclusion of focus group, from the professor's aspect is that professors have to be more flexible in educational process that professors have to accept information technologies in educational process that professors have to follow student's behavior, new learning habits, as well as, to follow new information technologies platform for education. The professors emphasize that education has to be modern, innovative and inspirational. Professors, also, emphasize that they need to raise objective attitude with young generations, students, but, also, to follow new approaches of education. Professors have to be creator, innovator and artists in pedagogy.

\section{GOOD EXAMPLES OF EDUCATIONAL PROCESS IN BRITISH COUNCIL}

Good example of holistic marketing implementation on educational projects is British Council, which has great impact on education all over the world. British Council care about education, learning English, but also, about improving arts, literature, culture and social movements. British Council work on classroom educational process, develop of skills and on inspiration of students for further learning and development of knowledge. Elements of educational process are present in Figure 3.

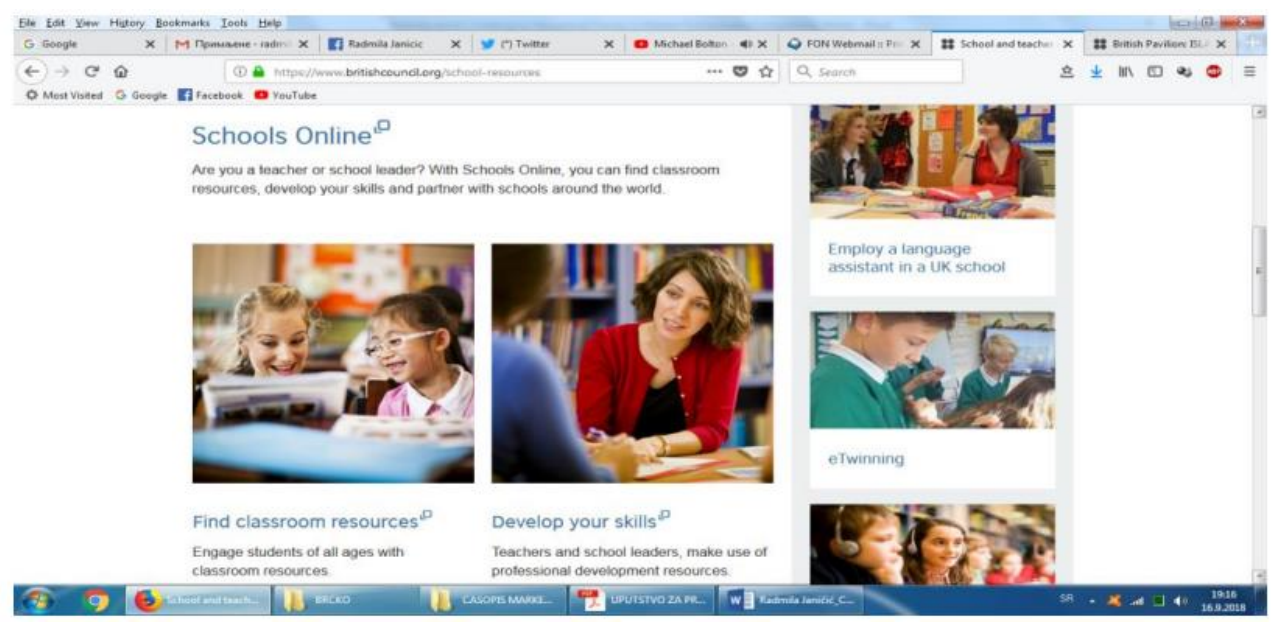

Figure 3. British Council learning process

Source:https://www.britishcouncil.org/school-resources

British Council cares about arts, education and society. British Council creates friendly knowledge and understanding between the people of the UK and other coun- 
tries. Through their arts, education and society programs, they give opportunities to hundreds of millions of people worldwide each year.

Arts are a cornerstone of the British Council's mission to create a friendly knowledge and understanding between the people of the UK and the wider world. They find new ways of connecting with and understanding each other through the arts, to develop stronger creative sectors around the world that are better connected with the UK. The mission of British Council is to bringing people together to share expertise and innovation, enrich and improve teaching and learning and open up new opportunities across the world. British Council base their work on learn, share and succeed. They organize every year conferences all over the world about all aspects of education. In that way they improve education in the world and building bridges with people, in order to be together in better education, in raising awareness about arts projects and raise awareness about social movements. British Council build platform for improving and development of education, arts and social movement worldwide. British Council works for society and helps people and institutions to contribute in more inclusive, open and prosperous world to bring about positive change in their society. Their work helps people to have their voice heard and access opportunities to shape their own futures.

\section{CONCLUSION}

Theoretical analysis, comparative analysis, examples from practice and focus group with professors about challenges of holistic marketing implementation in educational process, give conclusion that it is necessary to innovated marketing strategies in the field of leading of education. Conclusion is that it is necessary to improve support of society about education. Conclusion is that holistic marketing approach has impact on social movements. Through strategies of internal marketing, integrated marketing, social responsible marketing, social marketing and relationship marketing improve educational process in world.

Professors, as member of focus group, emphasize that it is important to improve knowledge in fields of history, sociology, culture and arts, through modern media, multimedia and digital, interactive movies. In that way young people can get more knowledge. Professors emphasize that it is necessary to make connection between professors all over the world in order to improve education.

Modern educational institutions accept multimedia, digital approach, as well as, holistic marketing approach. Conclusion is that good traditional ways of marketing planning of educational process have to stay, but it should be improve with modern, multimedia, digital approach.

The conclusion of focus group, from the professor's aspect is that professors have to be more flexible in educational process that professors have to accept informa- 
tion technologies in educational process that professors have to follow student's behavior, new learning habits, as well as, to follow new information technologies platform for education. The professors emphasize that education has to be modern, innovative and inspirational. Professors, also, emphasize that they need to raise objective attitude with young generations, students, but, also, to follow new approaches of education.

Professors have to be kind and honest with their students. Professors have to give to student's knowledge, innovation approach in science, inspiration and motivation. Professors have work with love and passion, to make good educational atmosphere for learning. Professors have to improve holistic responsibly approach. The future of education will be truth (Janicic, 2017).

\section{LITERATURE}

Belch, G., Belch, M.. (2012), Advertising and Promotion-An Integrated Marketing Communications Perspective, McGraw-Hill, New York.

Blakeman, R. (2006), Integrated Marketing Communication, Mc Millan, Toronto.

David, P. (2005), Integrated Marketing Communication, Elsevier Inc., Toronto:

Denegri, J. (2012), Modernism - avant-garde, Official Gazette, Belgrade (in Serbian).

Denegri, J. (2016), Post-war neo-avant-garde modernism - postmodernism, Official Gazette, Belgrade (in Serbian).

Filipović, V., Kostić Stanković, M. (2011), Public relations, Faculty of Organizational Sciences, Belgrade (in Serbian).

Filipović, V., Kostić Stanković, M. (2011), Marketing management, Faculty of Organizational Sciences, Belgrade (in Serbian).

Filipović, V., Janicic, R. (2011), Strategic marketing, Faculty of Organizational Sciences, Belgrade (in Serbian).

Larry, P. (2008), Strategic Integrated Marketing Communication, Elsevier Inc., Toronto.

Janicic, R. (2017), Truth in Marketing and Education, Conference about Marketing, Athens Institute for Research and Education, Atiner, Athens.

Janicic, R. (2018), Modern Process in Education, Conference New Technologies in Education, British Council, Belgrade.

Kennet, C. (2008), Integrated Advertising, Promotion and Marketing Communication, Prentice Hall, New York.

Kevin, R. (2004), The Future Beyond Brands - Love mark, Power House Books. New York.

Kotler, Ph., Keller, L. (2017), Marketing management, 15th Edition, Prentice Hall, London.

Pelsmacker, P., Geuens, M., Bergh, V. (2007), Marketing Communications, Prentice Hall, London. 
Reid, N., King, W., DeLorme, E. (2008), “Top Level Agency Creatives Look at Advertising Creativity Then and Now", Journal of Advertising, Vol. 56, No. 3, pp. 245-258.

Terence, S. (2008), Advertising Promotion and Other Aspects of Integrated Marketing Communications, Prentice Hall, New York. 